ISSN 1027-5495. Functional Materials, 23, No.2 (2016), p. 261-267

doi:http://dx.doi.org/10.15407/fm23.02.261

(C) 2016 - STC “Institute for Single Crystals"

\title{
Comparative study of two rolling bond process for super-thick Q235B
}

\author{
Guanghui Zhao, Qingxue Huang, Cunlong Zhou, \\ Zhanjie Zhang, Lifeng Ma, Xiaogang Wang
}

\author{
Shanxi Provincial Key Laboratory of Metallurgical Device Design Theory \\ and Technology, Taiyuan University of Science and Technology, Taiyuan \\ 030024,Shanxi,China
}

Received November 25, 2015

\begin{abstract}
In paper, two rolling bond processes for heavy-gauge steel plate Q235B were studied and the processes were simulated by MARC software. The mechanical properties and microstructure at the interface were comparative analyzed for the two bonded plates using different rolling process. Using MARC software analysis for two rolling process, the ratio of equivalent stress in rolling process /yield stress in current temperature from surface to center portion was relatively uniform for rolling bonded.

Keywords: heavy-gauge steel plate; rolled bonding; comparative study; MARC simulation

В работе исследовано два процесса прокатки толстопрофильных стальных пластин Q235B и проведено моделирование этих процессов с помощью программного обеспечения MARC. Проведен сравнительный анализ механических свойств и микроструктуры на межсразной границе для двух пластин, полученных с помощью разных процессов прокатки. С помощью компьютерного моделирования MARC проанализировано отношение эквивалентного напряжения в процессе прокатки к границе текучести при данной температуре от поверхности к центральной части образца.
\end{abstract}

Порівняльне дослідження процесів прокатування пластин Q235B надвеликої товщини. Гуанхуей Чжао, Цинсюе Хуан, Цюньлун Чжоу, Чжанизе Чжан, Ліббэн Ма, Сяоган Ван

У роботі досліджено два процеси прокотування товстопрофільних сталевих пластин Q235B і проведено моделювання цих процесів за допомогою програмного забезпечення MARC. Проведений порівняльний аналіз механічних властивостей і мікроструктури на міжфразній межі для двох пластин, зв'язаних за допомогою різних процесів прокотування. За допомогою комп'ютерного моделювання MARC проаналізовано відношення еквівалентної напруги в процесі прокотування до межі текучості при даній температурі від поверхні до центральної частини образца.

\section{Introduction}

There is great market demand for large single-thick steel plate in some special occasions such as heavy machinery, water conservancy, armor, dam. In traditional rolling, heavy ingot is mainly the raw materials of heavy plate. However, the heavy ingot is thoroughly thick and the time of solidification cooling is very long, which led to serious segregation in the solidification process. Simultaneously, there are serious casting defects of shrinkage cavity, porosity and inclusion at the center of heavy ingot due to the solidification feeding and volume shrinkage. Using large rolling force and large reduction in the hot rolling process, the coarse as-cast microstructure can be crushed 


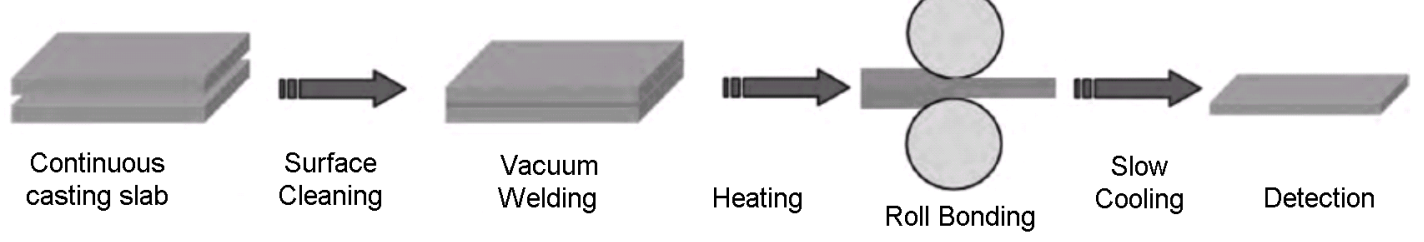

Fig.1. Production process of clad steel plate

and defects of porosity can be partially welded. But the steel plate will inevitably inherited the original as-cast ingot organization after rolling process. Consequently, it is hard to meet high performance for producing large heavy plate, especially for the heavy plate which requires the performance of $\mathrm{z}$-direction and ultrasonic testing requirements[1, 2]. Therefore, for exploring and practicing the preparation of thick slab of material, JFE company on behalf of many domestic and foreign research institutes and mills, researched and developed a variety of manufacturing technology. Using steel billet welded and manufactured by casting billet and vacuum hot rolling, JFE company successfully used in the production of heavy plate, which solved the internal quality of large steel ingot and small compression ratio [3].

Hot rolling bonding: making use of rolling mill produce composite plate. According to the strong force of the rolling mill and combined with thermal effect, two surface of compound metal are brokered and there is plastic deformation in whole metallic cross-section.

Simultaneously, the clean and activated surface is easy to form planar metallurgical combination under strong rolling pressure. Further, the fundamental difference between rolling of composite metal plate and single metal plate is that the rolling pass of composite metal plate must be subjected to a large reduction, particularly the reduction of initial rolling pass. Only in this way, it can promote to physical contact of composite surface. Therefore, it is necessary to explore the technology of heavy-gauge steel plate by the hot rolling bond and further research the effect on the properties of heavygauge steel plate [4, 5].In particular, different pass rolling process optimization has a significant impact on proprieties of composite plate and production costs of company. In this paper, two rolling bond processes for heavy-gauge steel plate Q235B were studied, organization and mechanical properties of which were analyzed. What's more, the two rolling bond processes of rolling bond were analyzed by nonlinear finite element software MSC.Marc.
Table 1. Chemical composition of the experimental Q235B steel(mass fraction,\%)

\begin{tabular}{|c|c|c|c|c|}
\hline $\mathrm{C}$ & $\mathrm{Si}$ & $\mathrm{Mn}$ & $\mathrm{P}$ & $\mathrm{S}$ \\
\hline 0.15 & 0.2 & 0.55 & 0.03 & 0.02 \\
\hline
\end{tabular}

\section{Experimental}

The raw material is Q235 casting slab, chemical composition as shown in table 1.

First of all, the billet was prepared and made surface treatment. The composite surface should be clean and grind smooth, which benefits to two kind of metal atoms mutual diffuse, realizing metallurgical bonding. Then it was batched and welded with clean surfaces faceto-face. After being implemented high temperature and long time heating in the chamber furnace, heavy slab was hot rolled bond by a strong rolling mill. Finally, slow stacking cooling and detection was used for hot rolled bond plate. The process is shown in figure 1 . The initial rolling temperature was controlled from $1020{ }^{\circ} \mathrm{C}$ to $1120{ }^{\circ} \mathrm{C}$ and the actual initial rolling temperature was $1056{ }^{\circ} \mathrm{C}$. Taking the hot rolling process under high temperature, low speed and high rolling reduction, the concreteness distribution of rolling reduction and rolling speed is shown in table 2 for the two rolling bond process. It was used high pressure water descaling when the first and second pass in both initial rolling and end rolling. In order to keep the steel straightness, the composite plate needed temper rolling one or two passes. Composite plate are not controlled cooling after hot rolling and the ACC only turned on back blowing device. Composite plate was straightened immediately by straightening machine. Then it began to stack cooling when the temperature of which dropped to $450-550{ }^{\circ} \mathrm{C}$ and the time of stack cooling was greater than $48 \mathrm{~h}$.

Performance of composite plate was analyzed. Flaw detection was conducted by ultrasonic flaw detector according to the GB/T77347734"composite plate ultrasonic inspection method". Tensile samples were processed into Standard circular $\varnothing 10 \mathrm{~mm} \times 120 \mathrm{~mm}$ on the basis of GB/T 228.1-2010 "Metal materials tensile test at room temperature"; V-notch standard sample was processed into $10 \mathrm{~mm} \times 10 \mathrm{~mm} \times 55 \mathrm{~mm}$ according to the GB/T 229-2007" Metallic mate- 
Guanghui Zhao at al. / Comparative study of two rolling bond process ...

Table. 2. The hot rolling process

\begin{tabular}{|c|c|c|c|c|c|c|c|c|c|c|c|}
\hline $\begin{array}{l}\text { Speed } \\
\text { of roll- }\end{array}$ & $\begin{array}{l}\text { Thick- } \\
\text { ness } \\
\text { Before }\end{array}$ & & Rolling & ess/Rolli & g pass/ T & ickness a & er rollin & Reduction & ratio & & $\begin{array}{l}\text { Thick- } \\
\text { ness af- } \\
\text { ter roll- }\end{array}$ \\
\hline \multirow{5}{*}{$15 \mathrm{r} / \mathrm{min}$} & \multirow{5}{*}{$400 \mathrm{~mm}$} & & 1 & 2 & 3 & 4 & 5 & 6 & 7 & 8 & \multirow{5}{*}{$80 \mathrm{~mm}$} \\
\hline & & \multirow{2}{*}{$\mathrm{I}$} & $380 \mathrm{~mm}$ & $335 \mathrm{~mm}$ & $280 \mathrm{~mm}$ & $225 \mathrm{~mm}$ & $170 \mathrm{~mm}$ & $120 \mathrm{~mm}$ & $90 \mathrm{~mm}$ & $80 \mathrm{~mm}$ & \\
\hline & & & $5.00 \%$ & $11.84 \%$ & $16.42 \%$ & $19.64 \%$ & $24.44 \%$ & $29.41 \%$ & $25.00 \%$ & $11.11 \%$ & \\
\hline & & \multirow{2}{*}{ II } & $350 \mathrm{~mm}$ & $300 \mathrm{~mm}$ & $243 \mathrm{~mm}$ & $190 \mathrm{~mm}$ & $135 \mathrm{~mm}$ & $91 \mathrm{~mm}$ & $80 \mathrm{~mm}$ & & \\
\hline & & & $12.50 \%$ & $14.29 \%$ & $19.00 \%$ & $21.81 \%$ & $28.95 \%$ & $32.59 \%$ & $12.09 \%$ & & \\
\hline
\end{tabular}

Table. 3. Mechanical properties of the Q235B clad steel plate

\begin{tabular}{|c|c|c|c|c|c|c|}
\hline Rolling process & State & Rel/MPa & $\mathrm{Rm} / \mathrm{MPa}$ & $\begin{array}{c}\text { Elonga- } \\
\text { tion/\% }\end{array}$ & $\begin{array}{c}\text { Impact en- } \\
\text { ergy/J }\end{array}$ & $\begin{array}{c}\text { Shear } \\
\text { strength/MPa }\end{array}$ \\
\hline I & Controlled rolling & 205 & 405 & 24 & 31 & 155 \\
\hline II & Controlled rolling & 265 & 465 & 30 & 51 & 286 \\
\hline
\end{tabular}

rials-Charpy pendulum impact test method." and GB/T 700-2006 "Metal material Summer than pendulum impact test method". Using ZBC2602 automatic impact testing machine, the shock temperature is $20{ }^{\circ} \mathrm{C}$. The organization structure and bond interface was respectively analyzed by Carl \& Zeiss optical microscope and scanning electron microscope(SEM).

\subsection{Mechanical properties}

By nondestructive ultrasonic flaw detection, there were cracks and lamination defects in $80 \mathrm{~mm}$ clad sheet steel using I rolling process, especially at the head and the tail of steel plate. But, the clad plate using II rolling process was no obvious defects, meeting 1 level requirements.

From the table 3, it illustrated that the I composite plate didn't met the mechanical properties of Q235 according to GB/T 700-700 "carbon structural steels" (2006), but II composite plate met. The bonding strength of composite plate was usually estimated through shear test evaluation and the better shear strength of layered composite material plate were more than $60 \%$ [3]. In this study, the pressure shear test showed: the I composite surface shear strength of rolled plate reached $38.2 \%$ for the tensile strength of its corresponding location and the II composite surface shear strength reached $61.5 \%$, above the requirement. These results showed the mechanical properties of rolling plate using process II were better than that using process I.

\subsection{Analysis of microstructure and bonded interface}

For heavy plate rolled bond, the mechanism of metal interface bonding is mainly mechanical mechanism, film theory and the theory of recrystallization [6]. According to these theory, gaps at the interface caused by the machining error were basically closed in the first rolling pass.

Under high temperature and strong rolling pressure, metal was to come into plastic deformation and hardened surface layers were burst. At this moment, the upper and lower fresh metal was burst through the crack of hardened surface layers and metal atoms of fresh metal became mutually embedded in each other. When two groups metal close to the magnitude of the distance between atoms, atoms attracted each other. During adjacent atoms was arranged in stable equilibrium spacing, the free electrons in outer layer of the two kinds metal atoms became common electronic to form metallic bonding. Adding diffusion layer formed by diffusible metal atoms in high temperature, hot rolling bond was achieved.

But the position of rolling bond was very rare in the first rolling pass. There were still inclusions in large areas of the interface. There were two main reasons for this situation: first, surface machining and grinding process failed to remove trace oxides, the second was due to the lower free energy at the gap, resulting precipitates aggregating to form inclusions. With the increase of rolling reduction rate, there had some rolling compaction effect for inclusions, causing inclusions discontinuous distribution at the bonding surfaces, but the shape of inclu- 


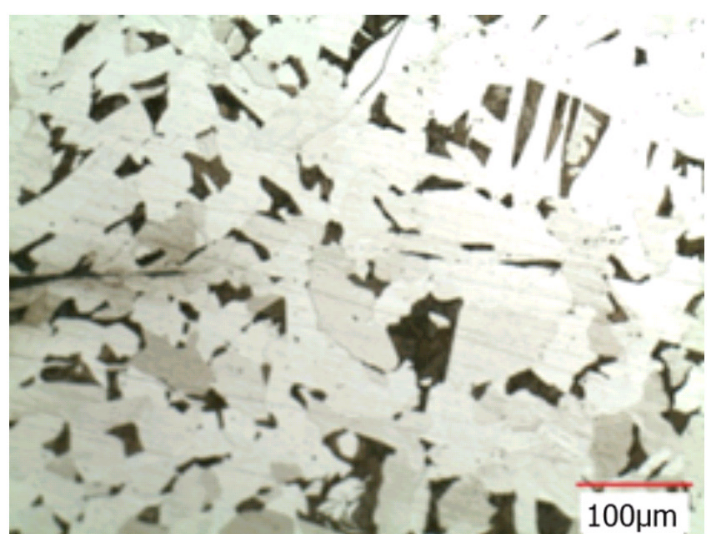

a)

Fig.2. Microstructure of clad steel plate: (a) I, (b) II.

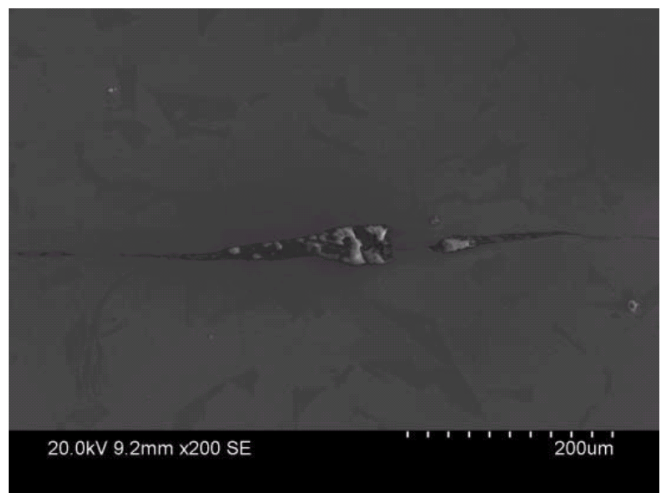

a)

Fig. 3. Microstructure of clad steel plate by SEM: (a)

sions at the interface was still very obvious. With the reduction rate continuing to increase, the center of the heavy plate generated plastic strain, rolling compaction effect for inclusions at the interface has been significantly increased, so the previous clear orientation distribution of inclusions began to enter state of dispersion of the distribution. These would greatly weaken the impediment of inclusion for metal bonding. Simultaneously, more and more grains were formed and bonding effect was gradually getting better [7].

Microstructure are shown in Figure 2. As can be seen from the Figure 2(a), there were nonuniform ferrite + pearlite structure, indicating that there was no good consistent plastic deformation in the center part; there was unbound area at the interface, indicating the bonding of center portion was inadequate and incomplete such hot rolling conditions, which was correspond to the results by ultrasonic flaw detection. Further by SEM analysis (as shown Fig 3(a)), there were long cracks and more inclusions in cracks at the bonded interface. Serious mixed crystal and cracks and inclusions defect at bonded interface reduced the

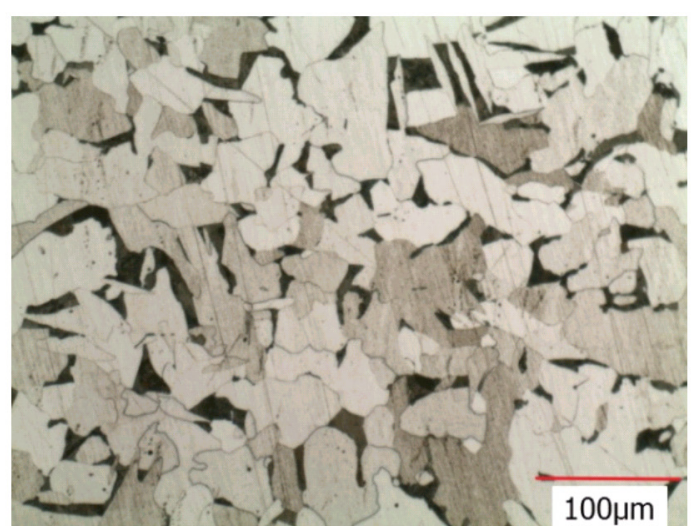

b)

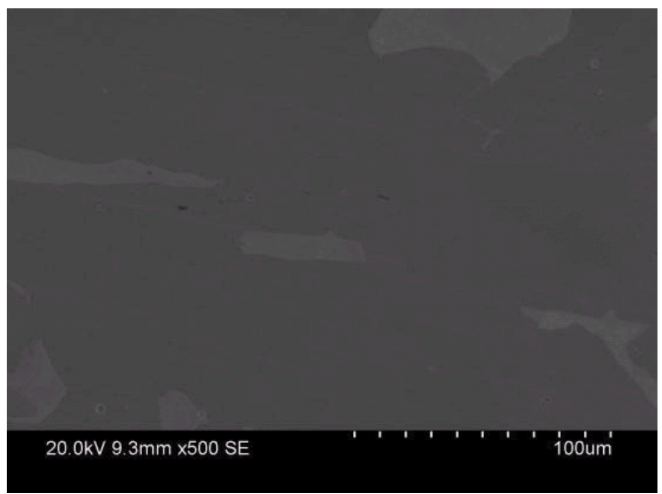

b)

mechanical properties of the rolled bond plate. Contrarily, as can be seen from the Figure 2(b), there were uniform and refined ferrite + pearlite structure and were no unbound area at the interface. What' more, there were well bonded interface by SEM analysis (as shown Fig 3(b)). These results showed the bonded interface of rolling plate using process II was better than that using process I.

\section{Results and discussion}

\section{Residual stress and strain analysis}

In this investigation, simulation of thick plate production process were analyzed by nonlinear finite element software MARC. Reversible hot rolling was realized by Model Section simulation of MARC[8]. In this paper, the different pass of rolling, the equivalent stress and equivalent strain on the thickness direction of situation are analyzed. The casting slab of vacuum hot roll bonding is mainly to study the deformation across the thickness direction. Its deformation law is the same of a whole slab. So the whole casting slab were simulated by Marc, according to the actual rolling process 


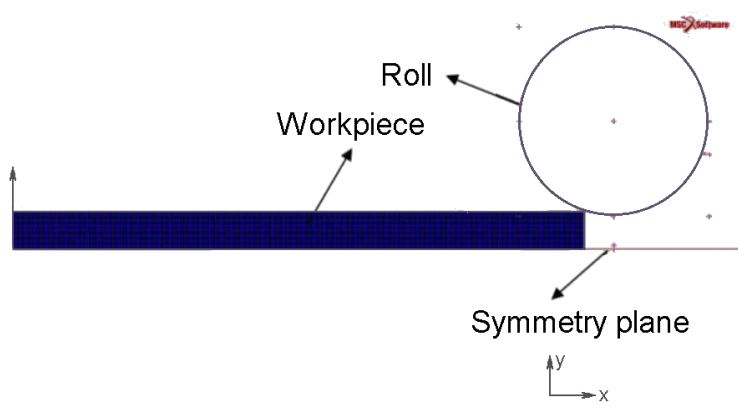

Fig.4. FEM simulation model for rolling process

simulation [9].Using 2D model to simulate the actual rolling process, the diameter rigid roller is $1000 \mathrm{~mm}$, slab size is $400 \times 1800 \times 3000 \mathrm{~mm}$, rolling parameters is shown in Table 2 and the symmetry model is shown in Fig 4.

Only when the ratio of equivalent stress in rolling process /yield stress in current temperature is higher than 1 , the metal generated plastic deformation. As can be seen from Figure 5, the ratio of equivalent stress in rolling process /yield stress of process II was bigger than that of process I at the first and second rolling pass. Also, the section of big ratio was deeper in the core of rolling plate using process II. For rolling bond, deformed core part was very important in the first few passes, which was beneficial to contacts of the being bonded metal and extrusion of fresh metal. Early bonding not only provided diffusion time for follow-rolling bond, but also provided convenience for easily crushing inclusions and oxides at the bonded surface. At the last pass, the big ratio section of the process II were deeper and wider than that of process
I in central portion. These results also showed deformation of surface and center portion was relatively uniform for rolling bonded plate using process II. The overall uniform deformation between the surface and the core section would help improve the overall mechanical properties of composite slab. As shown in Table 3, the mechanical properties of bonded plate using process II was better than that using process I.

Under high temperature and strong rolling pressure, metal was to come into plastic deformation and hardened surface layers were burst. At this moment, the upper and lower fresh metal was burst through the crack of hardened surface layers and metal atoms of fresh metal became mutually embedded in each other. When two groups metal close to the magnitude of the distance between atoms, atoms attracted each other. During adjacent atoms was arranged in stable equilibrium spacing, the free electrons in outer layer of the two kinds metal atoms became common electronic to form metallic bonding. Adding diffusion layer formed by diffusible metal atoms in high temperature, hot rolling bond was achieved. The exposed active surface was one of the necessary conditions for the bond. Another important factor in the bond was high enough pressure, only that to produce strong shear deformation, forming more dislocation motion. Therefore, the amount of deformation must be large for pass of rolling bond, so as to promote physical bonding component $[1,10]$.

Therefore, using of finite element software MARC, the equivalent strain of every pass was analyzed. As can be seen from Fig. 6, the section of big equivalent strain was deeper in the

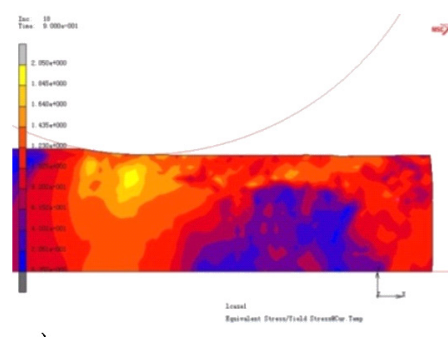

a)

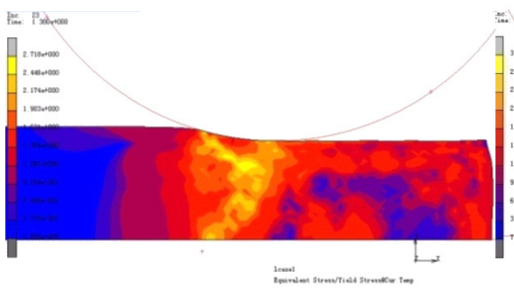

d)

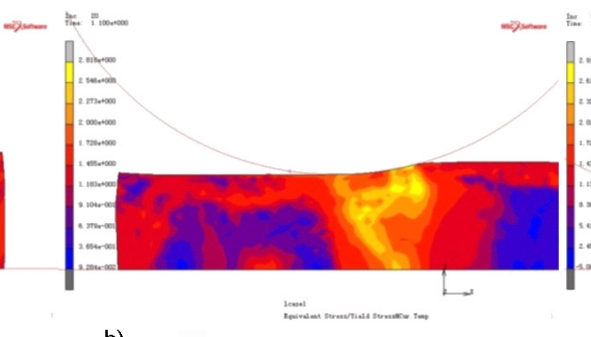

b)

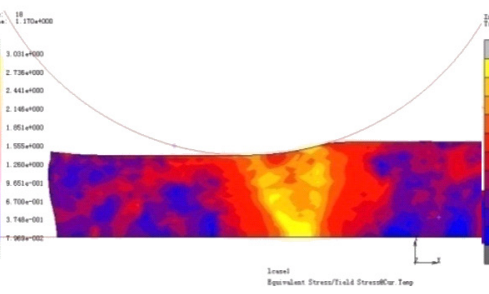

e)

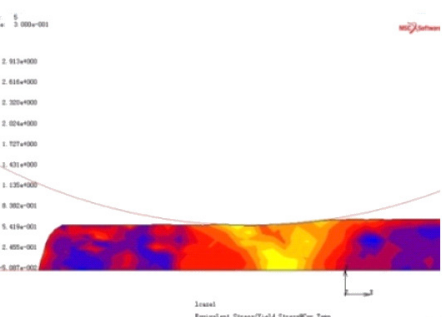

c)

Fig. 5. Nephogram for the ratio of equivalent stress in rolling process /yield stress in current temperature: (a) I-first pass, (b) I-second pass, (c) I-last pass, (d) II-first pass, (e) II-second pass, (f) II-last pass 


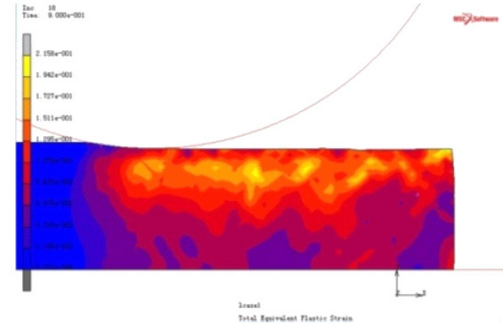

a)

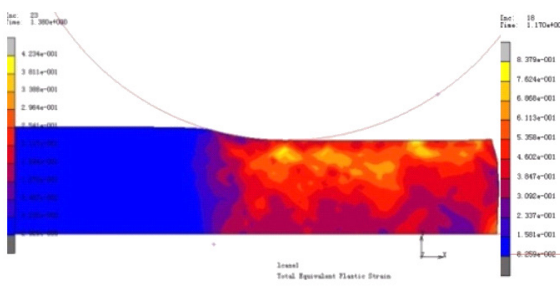

d)

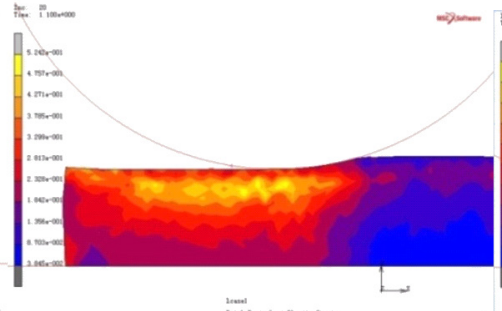

b)

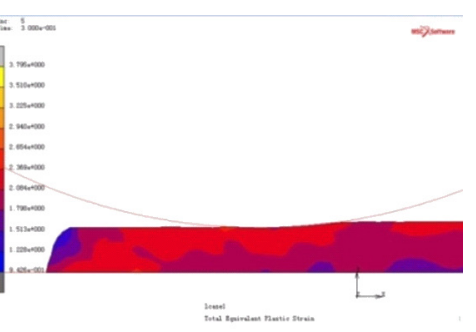

c)

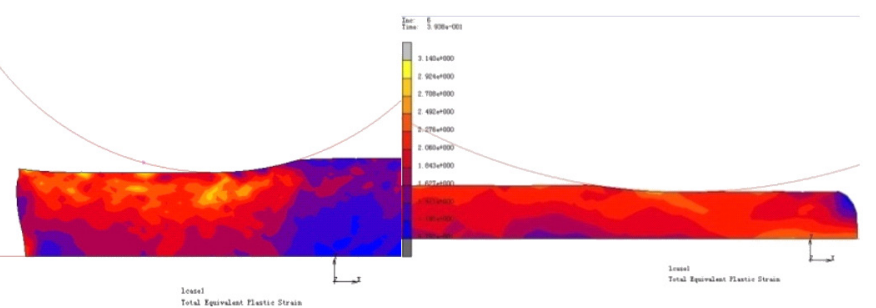

Fig.6. Nephogram of total equivalent plastic strain in hot rolling: (a) I-first pass, (b) I-second pass, (c) I-last pass, (d) II-first pass, (e) II-second pass, (f) II-last pass

core of rolling plate using process II. For rolling bond, deformation of bonding surface was beneficial to contacts of the being bonded metal and extrusion of fresh metal and provided probability for easily crushing inclusions and oxides at the bonded surface. At the last pass, the big equivalent strain section of the process II were deeper and wider than that of process I in central portion. These results also showed deformation of surface and center portion was relatively uniform for rolling bonded plate using process II. Under high temperature and big plastic deformation, the metal was prone to produce dynamic recrystallization. Big plastic deformation at the bonded surface of the plate could produce refined and uniform grain. It can be seen from Figure 2, refined and uniform grain was obtained. These results showed the plastic deformation in the core of rolling plate using process II was bigger than that using process I.

Figure 7 showed the equivalent strain diagram from the surface to the heart of rolled plate $(0, t / 4, t / 2)$ every pass. As can be seen from the figure 7: for the slab surface (0 section) every pass, equivalent strains using process I were less than that using process II; the two values were similar until the seventh pass; moreover, the last rolling pass, the results were opposite. For the $t / 4$ section every pass, equivalent strains using process I were less than that using process II; the two values were similar until the last rolling pass. For the $t / 2$ section every pass, equivalent strains using process I were less than that using process II until the last rolling pass. These results showed the equivalent strain in the core of rolling plate using

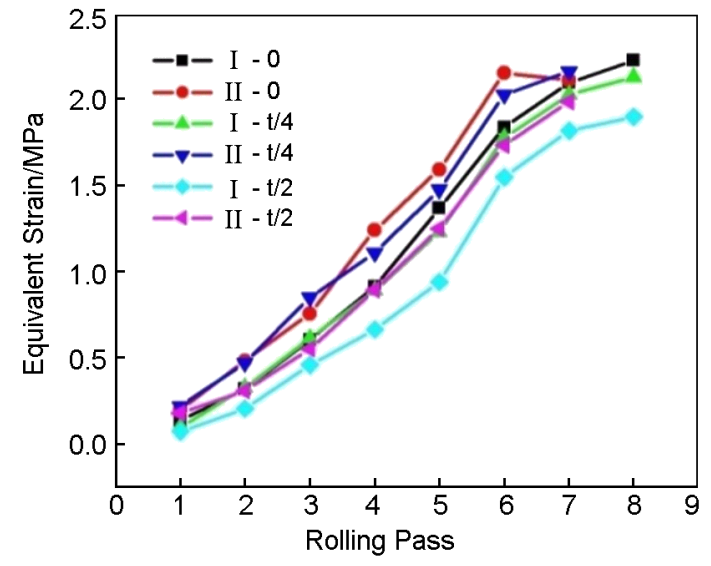

Fig.7. Distribution of equivalent strain in different deformation pass( $t$ is thick of the slab every pass)

process II was bigger than that using process I, which was beneficial to rolling bond.

When the rolling bond completed, the difference of equivalent strain among $0, t / 4$ and $t / 2$ section was large using process I, but the difference using process II was small. Using process II, the difference of equivalent strain from the surface to the heart of rolled plate $(0, t / 4, t / 2)$ was decreased, which made rolling deformation consistent across the thickness direction, increasing dispersion of inclusions at the interface and reducing the adverse effect for property due to the inclusion concentration [5]. From the view of production cost, process II reduced rolling pass, improving production efficiency. 


\section{Conclusions}

In this paper, two rolling bond processes for heavy-gauge steel plate Q235B were studied. The mechanical properties of rolling plate using process II were better than that using process I. Simultaneously, the bonded interface of rolling plate using process II was better than that using process I. For the rolling bonded plate using process II, there were uniform and refined ferrite + pearlite structure and were no unbound area at the interface; also, there were well bonded interface by SEM analysis. Moreover, using MARC software analysis for two rolling process, the ratio of equivalent stress in rolling process /yield stress in current temperature from surface to center portion was relatively uniform for rolling bonded plate using process II; also, the difference of equivalent strain from the surface to the heart of rolled plate $(0, t / 4, t / 2)$ was decreased using process II, which made rolling deformation consistent across the thickness direction.

\section{Acknowledgements}

This work wassupported by ProjectU1510131 of the National Natural Science Foundation of China, and the National Key Technology Research and Development Program in 12th Fiveyear Plan of China(2012CB722801).

\section{References}

1. Kimihiro Nishimura, Yoshiko Takeuchi. Tetsuto-Hagane,100(9), 1097, 2014. doi:10.2355/tetsutohagane.100.1097.

2. Li Wenbin,Yuan Siyu, Li Guanglong, Wang Changshun, Fei Jing, Heat treatment of meatals", 40(6), 49, doi:10.13251/j.issn.02546051.2015.06.012.

3. Nishida S, Matsuoka T., Wada T, JFE GIHO, 8(5), 1, 2004.

4. Patent no. CN101439348A, 2008,

5. Yu Wei, Zhang Yeming, HeChunyu, J. Univ.Sci. Techn. Beijing, 33(11), 1391, 2011, doi:10.13374/ j.issn1001-053x.2011.11.012

6. Daniel R. Cooper, Julian M. Allwood, J. Mater. Proc. Techn., 214, 2576, (2014) , doi:10.1016/ j.jmatprotec.2014.04.018

7. J. K. Kim, M. Y. Huh, J. C. Lee, J. Mater. Sci., 139, 5371, 2004.

8. Zhang Shihong, Liu Jinsong, "Advanced Materials Processing Technology and MSC. Marc realization", National Defence Industry Press,Beijing, China, 2015, P. 31.

9. Liu Jiyuan.."Research on deformation rules of Heavy GaugeSteel Plate clad rolling". ShenYang, Northeastern University, 27, 50. 2010.

10. Ceretti, E., Fratini, L.and Gagliardi, F., Giardini, C., "A new approach to study materialbonding in extrusion porthole dies". CIRPAnn. Manuf. Vol,Technol. 58 (1),pp,259-262.2009,Available: .http://dx.doi.org/10.1016/j.cirp.2009.03.010. 